\title{
Gender Based Utilization of Microfinance: An Empirical Evidence from District Quetta, Pakistan
}

\author{
Abdul Naeem ${ }^{1}$, Sana-ur-Rehman ${ }^{1}$ \\ ${ }^{1}$ Assistant Professor, Institute of Management Sciences, University of Balochistan, Quetta, Pakistan \\ Correspondence: Abdul Naeem, Assistant Professor, Institute of Management Sciences, University of \\ Balochistan, Quetta, Pakistan. E-mail: naeemyz@yahoo.com
}

Received: July 11, 2016

doi:10.5539/ibr.v9n10p162

\author{
Accepted: July 25, 2016 \\ Online Published: September 18, 2016 \\ URL: http://dx.doi.org/10.5539/ibr.v9n10p162
}

\begin{abstract}
This study examines the impact of microfinance on gender based income generating activities of the Khushhalli Bank Ltd client's in urban zone of district Quetta during year 2011. The Primary data was collected through structured questionnaire from 80 clients ( 60 beneficiaries and 20 non-beneficiaries) by adopting cross sectional experimental design.

In order to analyze the collected data the t-tests were applied. The results show that the microfinance has a positive impact on both male as well female beneficiaries as compare to non-beneficiaries in term of increase in business performance. It has non-significant impact on average sale revenue of both male as well as female micro-entrepreneurs. Whereas it has a significant impact on average net profit, average fixed assets as well as average net worth of the male but having non-significant impact on female established micro-entrepreneurs. Comparison of gender based business performance reveals that the microenterprises operated by male are able to generate better revenue and net income performance also the same results are obtained in case of enhancement in fixed assets as well as net worth. So we may confidently say that male clients are able in utilizing the microfinance services more effectively as compared to female.
\end{abstract}

Keywords: microfinance, micro-enterprise, micro-entrepreneur, sale revenue, net profit

\section{Introduction}

In the Balochistan province of Pakistan woman are particularly responsible for household activities such as raising kids, cooking and maintaining house. Most of the women are bound to stay within home premises, but few are involved in some income generation activities too. However, income generation by women has never been recognized by the society. Women of Balochistan have potential to play a vital role in economic growth of families and communities if financial hurdles are removed and societal discriminations are overcome. It is a need of the time that female should share equally with male counterparts in economic activities and to support families more effectively in monitory terms.

The Governments of developing countries are providing microfinance services through Microfinance Institutions (MFIs) to the deserving communities of the societies. By this strategy Governments are trying to improve people access to financial services, such as microcredit and insurance facilities in order to empower them financially. In absence of government support members of the poor communities continue to rely on meager self-finance or financial assistance from informal sources to initiate microenterprises at local level. This ultimately reduces their profitability and entrepreneurial thrill. The poor women, as a major portion of our population are affected from abject poverty. But such a marginal section of a society might be effectively assisted and empower through provision of microfinance services (ADB, 2009).

The Government of Pakistan considers the extension of microcredit as its "frontline strategy" in order to fight poverty. Among others one of the Government's objects is to stabilize its economy by promoting microenterprises. To achieve this, the Government of Pakistan has launched various integrated rural support programs. It has, also, allowed various NGOs and granted licenses to various Microfinance Banks to start operations. Government has also encouraged commercial Banks to open windows to promote microfinance to eradicate poverty. As a result, number of MFIs, NGOs and Microfinance Banks are operative in Pakistan in general and Balochistan in particular. However, the impacts of microfinance institutions on its user need to be 
evaluated. The main focus of this research study is to evaluate whether the men or women are more positively benefited from microfinance credit facilities provided by the Khushhalli Bank Ltd in district Quetta of Pakistan.

\section{Literature Review}

\subsection{Microfinance}

The concept of microfinance is initiated by well-known economist and noble laureate Dr. Mohammad Younas founder of the Grameen Bank in Bangladesh. The basic motive of microfinance is provision of finance to the poor for developing small enterprises. The small amount of loans is extended to the poor borrowers typically for a short term (a year or less), and are collateral free in nature requiring repayments in weekly installments. The main characteristic of microfinance is its ability of providing collateral free microloan (Asia Focus, 2010). The poor who can't operate or initiate businesses due to the shortage of capital may get benefit from microfinance services provided by microfinance organizations (Khandker, S., 2001). The researcher had agreed on this point that access to financial services is essential for the poor to enhance productivity, assets creation, income generation and achieve food security. So in comprehensive words Microfinance is basically a provision of small scale credit, and insurance to fulfill needs of poor entrepreneurs (Thapa, 2006). But lack of income and resources force the poor to take loans to meet basic necessities of life whereas the number of collateral leaves them at the mercy of the informal money lenders (The state of Pakistan's Economy, 2005). It has been observed that informal creditor's charges very high markup leaving borrowers highly indebted. In such a situation the poor definitely looks towards the government established microfinance institutions or financial intuitions runs by the nongovernment organization as they charge very nominal interest rate.

\subsection{The Khushhali Bank Limited: An Overview}

The Khushhali Bank Limited was established in year 2000 by the Government of Pakistan as part of its poverty reduction strategy and Microfinance Sector Development Program (MSDP). The government has developed MSDP with assistance of Asian Development Bank. The Khushhali Bank Limited work under supervision of the State Bank of Pakistan and major commercial banks are its shareholders (Khushhhali Bank Limited, 2012). It is the country's first licensed microfinance institute and has a mandate to provide retail microfinance services within country. It acts as facilitator for stabilizing the government newly launched microfinance projects.

The Khushhali Bank Ltd is today consider as country's largest microfinance bank in Pakistan in terms of its operations, coverage and impact in all four provinces of the country, Jammu and Kashmir and tribal areas.

\subsection{Gender Based Performance}

Magill and Meyer (2005) have revealed in an empirical study at Ecuador that majority of women micro-entrepreneur in the study area are economically active as compared to male. The main reason for higher participation of women in microenterprises; is the only opportunity available for them to participate as compare to men. A Sri-Lankan study by Pushpakumara (2011) reveals that microfinance has more positively impacted women entrepreneur then men in terms of capital gains, monthly income and saving levels. Similar results are also found in the research study conducted by Akram \& Hussain (2011) at district Okara, Pakistan and Planet Finance study at Egypt (2008) that higher percentages of women clients as compare to men clients have revealed a positive impact from microfinance on their businesses performance.

Khandker, (2001) has reported that women generally experience relatively higher increase in business income because women are more credit constrained than man. Karlan \& Zinma (2010), in a study conducted in Manila, identify early entrepreneurial involvement as a main reason for women success as compare to male counterparts. So the experience of the entrepreneur also contributes in the performance of business operations. Whereas, a Bangladeshi study has shown quite contradictory results as participation in the microfinance programs did not improve ownership of the women clients as compare to men (Chowdhury, 2009). The main reasons for improvement in men's ownership is the male dominance in Bangladeshi society as most of the women handover their loans and business assets to their husbands and do not run businesses by themselves. Similarly it has been identified by Severine, K., (2009) in a research study at Tanzania that microfinance activities has more positively affected male owned enterprises as compared to female enterprises. The male entrepreneurs have generated higher level of assets, sale revenue and number of employment opportunities.

The research study at Nigeria has revealed that microfinance could not helpful in enhancement of growth and expansion capacity of microenterprises (Babajid, 2012).

The above reviewed literature showing mixed results of microfinance impact on male or female enterprises highlights to further investigate whether men have benefited and empowered more as compare to women in different context. The present study focuses in obtaining answer to the following research questions from 


\section{Balochistan Perspective:}

I. Does the access to microfinance services more helpful for men as compare to women in boosting of microenterprise's revenue?

II. Does the access to microfinance services more helpful for men as compare to women in growth of microenterprise's net income?

III. Does access to microfinance services more helpful for men as compare to women in increasing microenterprise's fixed assets?

IV. Does access to microfinance services more helpful for men as compare to women in enhancement of microenterprise's net worth.

\section{Methodology}

The cross sectional survey design is used for this study. The households having micro enterprises are taken as a unit of assessment. A sample comprising 80 respondents (40 males and 40 (females) who obtained loan from the Khushhali Bank Ltd are selected by using multistage cluster sampling. At first stage 60 respondents (30 males and 30 females) who obtained microcredit facilities at least two years prior to the conduct of the survey i.e. December $31^{\text {st }}, 2011$ are treated as beneficiaries (treatment group) and at second stage 20 respondents (10 males and 10 females) are selected from new entrants who have just obtained the microcredit facilities and developed enterprises treated as non-beneficiaries (control group).

The population of the study consists of all such borrowers of the Khushhali Bank Ltd, who have obtained loans and invested for microenterprise startups or supporting a running business. These clients belong to the urban zone of the district Quetta as the Khushhai Bank provides microfinance facilities only in urban area and does not extended its' services to the rural areas as per information provided by the regional office.

The study at first stage, compares changes in enterprise performance by comparing beneficiaries with non-beneficiaries to see microfinance impact. The study anticipates better status of beneficiaries in term of enterprises' sale revenue, net income, increase in fixed assets and net worth of business as compare to controlled group. In order to reveal the final conclusion at the second stage, the differences of performance among the two groups are studied on the basis of gender (males and females).

The primary data is collected through structured questionnaires from a sample of 80 Bank clients. These are those clients who have invested microcredit in microenterprises; these clients are identified with the help of the bank field staff. An experienced team of MBA students having research knowledge have helped in data collection through self-administered questionnaires.

For ensuring completeness and quality of data, a field data editing is carried out at the end of the each day after analyzing the each questionnaire to minimize the chances of errors. The collected data is entered into software Statistical Package for Social Scientists (SPSS) version 16 for analysis purpose on daily basis.

\section{Findings of the Study}

\subsection{Demographic Profile}

\section{Marital Status}

Majority of the respondents under study are males i.e. $62.5 \%$ while $55.0 \%$ are female, whereas, $37.5 \%$ male and 45.0\% female are un-married. From the data it is inferred that the high percentage of both married male and female are interested in seeking microfinance services as compared to unmarried. 
Table 1. Demographic Information of Respondents

\begin{tabular}{|c|c|c|}
\hline Demographic Variables: & $\begin{array}{l}\text { Gender } \\
\text { Male } \\
(n=40)\end{array}$ & $\begin{array}{c}\text { Female } \\
(\mathrm{n}=40)\end{array}$ \\
\hline \multicolumn{3}{|l|}{ Marital Status } \\
\hline Married & $62.5 \%$ & $55.0 \%$ \\
\hline Un-married & $37.5 \%$ & $45.0 \%$ \\
\hline \multicolumn{3}{|l|}{ Level of Education: } \\
\hline Uneducated & $12.5 \%$ & $37.5 \%$ \\
\hline Primary & $35.0 \%$ & $30.0 \%$ \\
\hline Middle & $17.5 \%$ & $10.0 \%$ \\
\hline Matric & $15.0 \%$ & $12.5 \%$ \\
\hline Intermediate & $07.5 \%$ & $10.0 \%$ \\
\hline Graduate & $07.5 \%$ & $00.0 \%$ \\
\hline Master & $05.0 \%$ & $00.0 \%$ \\
\hline \multicolumn{3}{|l|}{ Family Size: } \\
\hline Less than 2 members & $00.0 \%$ & $00.0 \%$ \\
\hline 3 to 5 members & $25.0 \%$ & $37.5 \%$ \\
\hline More than 5 Members & $75.0 \%$ & $62.5 \%$ \\
\hline \multicolumn{3}{|l|}{ Income Level: } \\
\hline Rs. $2000-4000$ & $05.0 \%$ & $15.0 \%$ \\
\hline $5000-7000$ & $30.0 \%$ & $20.0 \%$ \\
\hline $8000-10000$ & $27.5 \%$ & $35.0 \%$ \\
\hline $11000-15000$ & $17.5 \%$ & $17.5 \%$ \\
\hline $16000-20000$ & $10.0 \%$ & $07.5 \%$ \\
\hline 21000 or more & $10.0 \%$ & $05.0 \%$ \\
\hline
\end{tabular}

\section{Level of Education}

The education level of respondents indicates (Table 1) that the high percentage (37.5\%) of females as compare to males $(12.5 \%)$ are un-educated and more than half $(62.5 \%)$ of the females having primary to intermediate level of education., None of them have graduate or master level of education. Whereas, for the males, majority of the respondents $(87.5 \%)$ are educated and only $12.5 \%$ are uneducated. This status shows that females are lacking behind in the level of education in Balochistan province.

\section{Family Size}

Composition of family pattern revels that $75.0 \%$ males and $62.5 \%$ female belong to family having more than 5 household members, whereas, $25.0 \%$ male and $37.5 \%$ female have 3-5 household members. This means that majority of the male are bearing burden of larger family as compare to female. The main reason for the large number of married male involvement in business operations and seeking microfinance services is that they are the sole bread earner for their family.

\section{Income Level}

Majority of the respondents $57.5 \%$ males and $55.0 \%$ females belong to Rs. 5,000-10,000 income brackets, while $27.5 \%$ male and $25.0 \%$ females belong to Rs. $11,000-20,000$ income brackets. Some $15.0 \%$ females and 5.0\% male, also, belong to very low income bracket i.e. Rs. 2,000 - 4,000. Analyzing the different income levels reveals that majority of the respondents availing microfinance services belongs to very low income level.

\subsection{Impact of Microfinance on Micro-enterprise Performance}

In this research study the micro-enterprise performance is judged by measuring microfinance impact on four variables i-e Average Annual Sale, Net Income, Fixed Assets and Enterprise Net Worth. Firstly, the changes in client's micro-enterprise's performance on the basis of beneficiaries versus non-beneficiaries are analyzed to check the microfinance impact. The study infers that beneficiaries business have shown better performance in term of micro-enterprise's sale revenue, net income, fixed assets and net worth as compared to that of non-beneficiaries. In order to reveal the gender impact, at the second stage, the enterprises' performance difference on the basis of male and female is analyzed. 
Table 2. Impact of Microfinance on Average Annual Sale

\begin{tabular}{lccccc}
\hline Gender & \multicolumn{2}{c}{ Average Annual Sales } & \multicolumn{2}{c}{ Mean Difference } \\
& Beneficiaries & Non-Beneficiaries & *Amount & \% & t-test Value \\
\hline Male & $1,91,193$ & $1,52,600$ & 38,583 & 25.29 & 0.819 \\
& $\mathrm{n}=30$ & $\mathrm{n}=10$ & & & $(0.418)$ \\
Female & $1,57,973$ & $1,39,000$ & 18,973 & 13.64 & 0.458 \\
& $\mathrm{n}=30$ & $\mathrm{n}=10$ & & & $(0.650)$ \\
\hline
\end{tabular}

*All Amounts are in Pak. Rupees. Values in parenthesis represent significance level.

Table 2 indicates gender wise average annual sale by the business activities developed by clients of both groups (beneficiaries and non-beneficiaries). The results show that the average annual sale generated by male and female (beneficiaries) is higher than (non-beneficiaries) micro-entrepreneurs. The average annual sale of male beneficiaries is $25.29 \%$ higher than male non-beneficiaries and in case of female beneficiaries business it is $13.64 \%$ higher as compare to female non-beneficiaries. The means difference $(\mathrm{t}-\mathrm{value}=0.819)$ of average annual sales among male beneficiaries and non-beneficiaries is non-significant $(P=0.418)$ and for female ( $\mathrm{t}$-value $=$ $0.458)$ non-significant too $(P=0.650)$. So we may infers that the increase in average sale revenue generated by both male \& female beneficiary's micro-entrepreneur shown a no-significant impact in term of increase in revenue as compare to male and female non-beneficiaries.

By comparing average annual sale on gender basis it is inferred that the male developed businesses have generated higher average revenue than female micro-entrepreneurs. It is clear from the data given in the Table 2 that male micro-entrepreneurs are able in generation of high average annual sale from their microenterprises, which is almost double as compare to their female counterparts.

Table 3. Impact of Microfinance on Annual Net Income

\begin{tabular}{|c|c|c|c|c|c|}
\hline \multirow[t]{2}{*}{ Gender } & \multicolumn{2}{|c|}{ Average Annual Net Income } & \multicolumn{3}{|c|}{ Mean Difference } \\
\hline & Beneficiaries & Non-Beneficiaries & Amount* & $\%$ & t-test Value \\
\hline Male & $\begin{array}{c}88,143 \\
n=30\end{array}$ & $\begin{array}{c}43,880 \\
\mathrm{n}=10\end{array}$ & 44,263 & 100.87 & $\begin{array}{c}2.222 \\
(0.032)\end{array}$ \\
\hline Female & $\begin{array}{c}86,200 \\
n=30\end{array}$ & $\begin{array}{c}81,893 \\
\mathrm{n}=10\end{array}$ & 4,307 & 05.26 & $\begin{array}{c}0.115 \\
(0.288)\end{array}$ \\
\hline
\end{tabular}

*All Amounts are in Pak. Rupees. Values in parenthesis represent significance level.

The Table 3 reveals information about average annual net income earned by business enterprises developed by clients after acquiring funds from the Khushhalli Bank and making investment in microenterprises. The average annual net income of male \& female beneficiaries is higher than non-beneficiaries. The results show the microfinance has positive impact on the clients' business performance. The male beneficiaries are able to increase average annual net income by $100.8 \%$ as compared to male non-beneficiaries whereas female beneficiaries are successful in enhancing average annual net income by only $5.26 \%$ as compare to female non-beneficiaries.

The mean difference (t-value $=2.222)$ of average net income between male beneficiaries and non-beneficiaries is significant at 0.032 level of significance, whereas for female $(t-v a l u e=0.115)$ is not significant at 0.288 level of significance. From statistical analysis we may infer that both male \& female micro-entrepreneurs are able in controlling cost of business activities which results in enhancement of average net income.

By comparing the business performance on the basis of gender it is inferred that female micro-entrepreneur could not show better performance in generation of average annual net income as compare to male micro-entrepreneur. This enhancement in net income may create drastic improvement in male business performance as compare to female.

Table 4. Impact of Microfinance on Fixed Assets

\begin{tabular}{cccccc}
\hline Gender & \multicolumn{2}{c}{ Annual Average Fixed Assets } & \multicolumn{3}{c}{ Mean Difference } \\
& Beneficiaries & Non-Beneficiaries & Amount* & \% & t-test Value \\
\hline Male & 50,700 & 9,400 & 41300 & 439.61 & 2.827 \\
& $\mathrm{n}=30$ & $\mathrm{n}=10$ & & & $(0.008)$ \\
Female & 20,200 & 18,933 & 1267 & 6.69 & 0.127 \\
& $\mathrm{n}=30$ & $\mathrm{n}=10$ & & & $(0.904)$ \\
\hline
\end{tabular}

*All Amounts are in Pak. Rupees. Values in parenthesis represent significance level.

The Table 4 shows overall enhancement in average fixed assets of both male and female (beneficiaries) as compare to male and female (non-beneficiaries) micro-entrepreneurs. The male and female beneficiaries are successful in enhancing fixed assets at the rate of $439.61 \%$ and $6.69 \%$ respectively as compare to 
non-beneficiaries. The t-test value (2.827) for means comparison for fixed assets of male beneficiaries and non-beneficiaries entrepreneurs show significant difference at 0.008 significance level, whereas the same is not significant for female. So, we may infer from these results that males are more successful in enhancement of fixed assets of business as compare to female micro-entrepreneur. The enhancement in the value of average fixed assets of male micro enterprises are creating more positive role as compare to female micro-enterprises.

Table 5. Impact of Microfinance on Net Worth

\begin{tabular}{cccccc}
\hline Gender & \multicolumn{2}{c}{ Annual Average Net Worth } & \multicolumn{3}{c}{ Mean Difference } \\
& Beneficiaries & Non-Beneficiaries & Amount* $^{*}$ & t-test Value \\
\hline Male & 54,900 & 6,000 & 48,900 & 815 & 3.696 \\
& $\mathrm{n}=30$ & $\mathrm{n}=10$ & & & $(0.001)$ \\
Female & 18,817 & 17,220 & 1,597 & 9.27 & 0.189 \\
& $\mathrm{n}=30$ & $\mathrm{n}=10$ & & & $(0.851)$ \\
\hline
\end{tabular}

*All Amounts are in Pak. Rupees. Values in parenthesis represent significance level.

The Table 5 indicates enhancement in average net worth of micro-entrepreneurs by both male and female beneficiaries as compare to male and female non-beneficiaries. Both male and female beneficiaries' microenterprises are successful in increasing average net worth at the rate of $815 \%$ and $9.27 \%$ respectively as compare to non-beneficiaries businesses. The mean difference $(\mathrm{t}$-value $=3.696)$ of average net worth between beneficiaries and non-beneficiaries for male is significant at 0.001 significance level, whereas for female ( $\mathrm{t}$-value $=0.189$ ) is not significant because of 0.851 level of significance. This shows that enhancement in the value of average net worth of male micro enterprises will create more positive impact on their business performance as compare to female micro-enterprises.

\section{Discussion and Conclusion}

The present study examines impacts of microfinance facilities obtained by microenterprises from the Khushhalli Bank, Quetta, Pakistan. The results indicate that the beneficiaries are well in position to utilized microfinance to enhance businesses growth as compare to non-beneficiaries. It is also inferred that microfinance has positively impacted business performance of both male and female microenterprises. We can conclude that both male and female micro-entrepreneur are successful in showing positive performance of their micro-entrepreneur after acquiring microfinance facilities from microfinance bank. The present study has inferred same results in line with previous studies showing that male entrepreneur's businesses perform better as compare to female (Chowdhury., 2009). But the male micro entrepreneur are unable to show significant impact on average net sale and average net income whereas they are able to create significant impact on average fixed assets and average net worth of businesses. Whereas, women are unable to show significant on all four variables which is against of the results shown by Akram \& Hussain (2011) at district Okara, Pakistan and Planet Finance study at Egypt (2008).

While comparing the microenterprises performances on gender basis, the male as compare to female micro-entrepreneurs have generated higher sale revenue, net profit. They are also able in enhancement of fixed assets and net worth of their enterprises. The female micro-entrepreneurs are unable to show better business performance as compare to male counterpart. The main reasons revealed in this study are; that the female's microenterprises have shown low business performance because majority of female clients are either uneducated or having low level of education as compare to male. Also, most of the female are married and belong to low income group. As female of Balochistan are responsible for taking care of family members along animal rearing which negatively affects business performance as compare to male micro-entrepreneurs.

Besides the above mentioned reasons female entrepreneurs get very less opportunity to flourish business activities because of being the part of such a culture which is mainly male dominated. The female micro-enterprises could not developed and grow business activities as compare to male due to lack of business skill and access to the wholesale market to purchase merchandise on comparative prices. Un-ability to get business outlets in a proper market is also hampering to generate proper sale revenue and due percentage of return on investment. Due to above mentioned reasons female entrepreneurs are not able to increase fixed assets and generate net worth from invested funds whereas male are able to show much better performance in growth and development of their business activities.

\section{Recommendations}

I. The most of the female clients have initiated their business but could not run it more effectively due to lack of business related training and sufficient financial assistance. So it is recommended all MFIs 
should arrange essential micro business related training and provide sufficient funds to women for establishment of businesses.

II. Most of the female entrepreneurs spend their business funds for domestic needs as they are responsible to take care of family too. It is recommended that the government should provide special loan to support domestic expenses in addition to business loan.

\section{References}

ADPB. (2009). Promoting Women's Entrepreneurship in Tajkistan's Transition Economy through Gender Inclusive Design; Completion Report for Tajikistan Microfinance Systems Development Program.

Akram, M., \& Hussain, I. (2011). The Role of Microfinance in uplifting Income Level: A study of District Okara-Pakistan. Interdisciplinary journal of Contemporary Research in Business, 2(11), 83-94.

Asia Focus. (2010). Microfinance in Philippine, Federal Reserve Bank of San Francisco.

Babajid, A. (2012). Effects of Microfinance on Micro and Small Enterprises (MSEs) Growth in Nigeria. Asian Economic and Financial Review, 2(3), 463-477.

Chowdhery, M. J. A. (2009). Microcredit, Micro-enterprises and Self-employment of Women: Experience from the Grameen Bank in Bangladesh, Paper presented at the FAO-IFAD-ILO Workshop on Gaps, trends and current research in gender dimensions of Agricultural and Rural Employment: Differentiated pathways out of poverty Rome, 1-19.

Karlan, D., \& Zinman, J. (2010). Expanding Microenterprise Credit Access: Using Randomized Supply Decisions to Estimate the Impacts in Manila. Innovations for Poverty Action. M. I. T. Jameel Poverty Action Lab, 1-36.

Khandker, S. (2001). Does Micro-Finance Really Benefit the Poor? Evidence from Bangladesh. Asia and Pacific Forum on Poverty, Asian Development Bank, Manilla.

Magill, J. H., \& Meyer, R. L. (2005). Microenterprises and Microfinance in Ecuador. Result of the 2004 Baseline Study of Microenterprises. United States Agency for International Development (USAID), 1-161

Planet Finance. (2008). National Impact of Microfinance in Egypt. Study conducted by Planet Finance, the Microfinance Platform, 1-100.

Pushpakumara. (2011). Impact of Gender on Effective Utilization of the Microfinance Credit Facilities in Sri Lanka. The Faculty of Commerce and Management Studies, University of Kelaniya, Kelaniya, Sri Lanka, $1-11$.

Severine, K. (2009). Microfinance and Enterprises Performance in Tanzania: Does Gender Matter? Proceeding of the $10^{\text {th }}$ Annual Conference, IAABD, 125-131.

Thapa, G. (2006). Sustainability and Governance of Microfinance Institutions: Recent Experiences and Some Lessons for Southeast Asia. Asian Journal of Agriculture and Development, 4(1), 17-18.

The State of Pakistan's Economy. (2005). First Quarterly Report year.

www.khushhaliBank.org.pk visited on (Saturday 16, 2012).

www.planetfinance.org

\section{Copyrights}

Copyright for this article is retained by the author(s), with first publication rights granted to the journal.

This is an open-access article distributed under the terms and conditions of the Creative Commons Attribution license (http://creativecommons.org/licenses/by/4.0/). 